\title{
The Postcolonial Writer in Performance: J. M. Coetzee's Summertime
}

\author{
Serena Guarracino \\ University of Naples 'L'Orientale' \\ serena.guarracino@gmail.com
}

\begin{abstract}
This essay focuses on the elaboration of postcolonial literature as an event emerging from the interaction among the many and diverse agencies which allow the postcolonial work to come into being. This formulation both highlights the repetition of tropes in postcolonial literature and the variations to the tropes themselves, which can become ethically and politically relevant by creating an interruption in accepted notions of what a postcolonial work should sound like. Following this lead, the essay will outline a methodological approach which interprets the literary work as a performative act in the complex nexus of discourses constituting the postcolonial writer as a figure of the global collective imaginary, taking as case study J. M. Coetzee's work with particular focus on his Nobel Prize lecture and the third instalment of his memoir series, Summertime (2009). His work, together with others, is taken as a symptom of how public lectures and statements, together with the literary work proper, have all become an expression of the writer's own performativity as a writer; while these phenomena have an impact on literature as a whole, the essay focuses on the postcolonial writer figure as historically endowed with what Kobena Mercer has famously termed "the burden of representation."
\end{abstract}

Everything you write, including criticism and fiction, writes you as you write it. (J. M. Coetzee, Doubling the Point, 1992) 
J. M. Coetzee's last (to date) memoir Summertime greets the reader with a sense of displacement, as the eye wanders among many and diverse narrative voices. The five sections which make up the book are folded between two sets of anonymous notes - the first slot dated between 1972 and 1975, the last undated. All sections offer a variety of linguistic and typographical devices, requiring constant interpretation by a reader who is often mirrored by one or more reader-characters. The five chapters are titled after each of the interlocutors interviewed by Mr. Vincent, a scholar who is working on a book on the late South African writer J. M. Coetzee; the reader meets all the interviewees either as delivering their story or reviewing its transcription for publication. This framework explicitly addresses the issue of authorship, as author of each section may be considered each interviewee, Mr. Vincent, and/or the namesake J. M. Coetzee, who is in due time identified as the writer of the notes welcoming the reader into the book.

This triangulation between writing, reading and editing in Summertime works as a fertile ground to tackle the wider question of the performativity of the postcolonial writer in contemporary Anglophone literature. The literary work, happening in the timespace network weaved together by writer, text and reader, hence emerges as an 'event'; this category, first elaborated by Derek Attridge in his own work on Coetzee (discussed later in this essay ${ }^{1}$ ), has been gaining a wider resonance in recent work by prominent literary theorists, including Terry Eagleton's The Event of Literature (2012; cf. also Szafraniec 2007). By intertwining these critical insights with Graham Huggan's argument on the 'postcolonial exotic', I intend to sketch out some preliminary considerations on literature and performativity in postcolonial writing: my aim is to confront the role of readers - including academics - in the creation of the work of literature, but also to reconsider the role of the writer as a public figure and the way it becomes, in its turn, a theme in writing.

\section{Performing postcolonial literature}

Literature actually hovers on the border of what 'is' performance according to historical and cultural traditions, and what can be studied 'as' performance, a distinction offered by Richard Schechner in his introduction to performance studies (2013: 30). As will be discussed later, there are moments on the contemporary literary scene which one can easily define as performances, at least broadly - readings, book launches, conferences and prize acceptance lectures, all instances where a bodily presence performs the role of 'writer' on a public stage. Yet there is also a wider performativity to the literary text (or 'event') and to how it defines 'the writer' or 'the work of literature' in a given context. If Eagleton spends some effort to define what "people at the moment call a piece of writing literary" (2012: 25), this must be taken as a sign of the constantly shifting nature of the 'literary': yet it also points to the fact that texts or acts become literary only by the joined effect of many and diverse conditions, or better by being "instantaneous 
productions intrinsic to interactions between various kinds of forces", to borrow from Cliff Stagoll's definition of the Deleuzian event (2005: 87). To think of literature as event means to stress its transient state against the apparently stable nature of the written text - a text that is, or may be, performed into 'literariness' by each reading, including academic readings and writings.

Attridge refers - though in passing (2004a: $151 \mathrm{n} 16)$ - to Deleuze's formulation by preferring 'event' over 'act', a terminological choice the scholar explains elsewhere in the same work:

[...] to call the process whereby an inventive artifact comes into the world an act is to misrepresent it; it is as much an event that happens to the inventor, and to the culture within which the invention takes place, as it is a willed action of a conscious individual (55).

Hence, a literary text is not to be read or interpreted - or even written - but 'performed' into being, as Attridge argues in a more recent essay (cf. 2011). Here he refers to recent developments in performance theory by underlining literature's ability to 'do' things, to excite affects or emotions as intensely as the 'real' thing; ${ }^{2}$ the result is a "performed emotion" (339) happening through the use of language 'as' literature: "as literature, [the language of a work] performs" the emotions narrated onto the reader, shaping an experience which "replicates modes of thinking and feeling in the non-literary domain" (333).

Although Attridge does not refer here to J. L. Austin's work on performative utterances, a distinct echo of the recent use of Austin's work by Judith Butler is detectable, although a dissonance is also perceptible which may be worth exploring here. In Attridge's essay, it is eventually the writer who emerges as the main 'performer' of the literary work, with the reader called to respond to the author's linguistic modulations. Pace Barthes' death of the author, ${ }^{3}$ Attridge's reading presupposes and reinstates the pre-eminence of the writer's agency into the shaping of the literary work: "it is the artist's manipulation of the resources of the medium (and this includes both material resources and the habits and expectations of those engaging with the work) that creates the impression of an affective response" (2011: 339).

On a rather different note, Butler confronts Austin's notion of illocutionary speech with Althusser and Derrida's theories to dislocate the subject (speaker or writer) as the original agent behind any linguistic utterance:

[...] if a performative provisionally succeeds [...], then it is not because an intention successfully governs the action of speech, but only because that action echoes prior actions, and accumulates the force of authority through the repetition or citation of a prior and authoritative set of practices (Butler, 1997: 51).

This repetition of previous practices is also at the heart of performance theory, where "restored behaviors" are the many instances in everyday life where "even if I feel myself wholly to be myself, acting independently, only a little investigating reveals that 
the units of behavior that comprise 'me' were not invented by 'me"' (Schechner, 2013: 34). Butler, proceeding from Foucault, calls this authoritative set of practices a "regime of truth", the framework which makes the narrative self recognizable by itself and others: "what I can 'be', quite literally, is constrained in advance by a regime of truth that decides what will and will not be a recognizable form of being" (Butler, 2005: 22). What I mean to explore in the following pages is how the 'postcolonial' can be considered a set of restored behaviours, or a regime of truth, and how the postcolonial text probes and exposes the limits of this regime by its own event-ness, challenging the apparent fixedness of received social and cultural frameworks.

\section{The accountability of postcolonial writing}

The 'postcolonial' in the definition 'postcolonial writing', as emerges today from the publishing industry and the academia, hovers between the realms of postcolonialism and postcoloniality as described by Graham Huggan in his The Postcolonial Exotic. Here, postcolonialism is defined as "an anti-colonial intellectualism that reads and valorises the signs of social struggle in the faultlines of literary and cultural texts" (2001: 6), while postcoloniality is a form of neocapitalist cultural capital, "a valueregulating mechanism [...] [where v]alue is constructed through global market operations involving the exchange of cultural commodities and, particularly, culturally 'othered' goods" (6). Although these two frameworks appear to be conceptually opposite, they are indeed "mutually entangled" (6), constantly working one alongside and against the other; to use a Saidean metaphor, they work in 'counterpoint' to one another, as overlapping territories where hegemony and resistance coexist on the very terrain of postcolonial literature (cf. Said, 1993: 51).

This wide-ranging landscape is very much indebted to the sort of commercial thirdworldism where postcolonial narratives are offered as interchangeable and accessible through "the consumption of literary works by much-travelled writers who are perceived as having come from, or as having a connection to, 'exotic' places" (Huggan, 2001: 19). This has led, among other things, to the emergence of the postcolonial author as a literary celebrity, whose apparent power as prominent subject of global literature at least in part resides in her/his ability to perform the 'postcolonial writer' persona not only through literary production but also in public lectures and statements. ${ }^{4}$

My point here is that, in the current regime of truth regulating the global cultural framework, the postcolonial literary work is to be considered, whatever the topic of the narrative, also 'an account of oneself' on the part of the writer, not only as a narrative which may or may not be concerned with life events, but also and especially in the sense of a postcolonial subject being accountable for one's own positioning as a writer. ${ }^{5}$ This take both highlights and complicates the relationship between postcolonial writing and life writing: Coetzee's works, as well as works by other writers I will not be discussing in depth here, resonate and sometimes explicitly address the writer's own public image as circulated in the media, and in this sense they inhabit the regime of 
truth of postcoloniality (in Huggan's sense) as a space which is both empowering and prescriptive.

This emerges in particular in Coetzee's memoirs Boyhood (1997), Youth (2002), and Summertime (2009), but also in recent works by other writers such as Rushdie's Joseph Anton (2012). Rushdie's memoir on the fatwa years explicitly stages the writer's selfpositioning and self-posing as 'migrant' writer by listing the most well-known tropes of postcolonial literature in the account of his 'making-of' as a writer:

If he hadn't become the writer he thought he had it in him to be, it was because he didn't know who he was. And slowly, from his ignominious place at the bottom of the literary barrel, he began to understand who that person might be. He was a migrant. He was one of those who had ended up in a place that was not the place where he began. Migration tore up all the traditional roots of the self. [...] He often felt meaningless, even absurd. He was a Bombay boy who had made his life in London among the English, but often he felt cursed by a double unbelonging (Rushdie, 2012: 53).

Here fictional autobiography becomes what Poyner, writing about Summertime, calls an "act of genre", where "it is through the form of these works [...], rather than their substance, that the most significant intellectualizing is done" (2009: 167). And form is also the place where the event-ness of these works, their emphasis on the moment of reading, can be found. Readership finds here a space of agency in the recurrent counterpoint between the events narrated in the text and any previous knowledge the reader may have of the same facts from different sources, such as the media or academic writing. In some of these works, such as Rushdie's and Coetzee's, this interplay is enacted by the use of the third person narrator instead of the more intimate first person. On a different note, in Jackie Kay's Red Dust Road (2012) it is irony which engages the reader in a playful emotional complicity with the narrating 'I'; while in Ahdaf Soueif's Cairo: My City, Our Revolution, the first person narrator directly addresses the reader with a you which draws her/him straight into this deeply affecting account of the Arab spring in Cairo: "we now have this information [on the follow-up of the revolution]. You, my reader, in more advanced form as you read these words than I as I race to write them in the summer of 2011" (2012: 8).

These recent works, though in deeply different ways, all address the vexed question of the role of life writing in postcolonial writing. Life writing practices have recently gone under heavy criticism as they risk to "become simply assertions of identity and its privilege" (Huddard, 2008: 13). In the postcolonial regime of truth, autobiography and life writing enact the performative of the 'public intellectual', thus remarking the social dimension of the literary work if and when it is recognized as such. ${ }^{6}$ The event of postcolonial literature hence emerges not only in "the normativity that governs the scene of recognition" (Butler, 2005: 23), but also in the relationality that grounds the very possibility of my own account of myself: "I give an account to someone, and [...] the addressee of the account, real or imaginary, also functions to interrupt the sense that this account of myself is my own" (36). Coetzee's work, and especially his recent memoirs, tackles these issues by showing how, while the literary work needs to 
conform to the regime of truth of the postcolonial, the event of postcolonial literature also exposes the limits of this regime, thus "engag[ing] in an aesthetics of the self that maintains a critical relation to existing norms" (Butler, 2005: 17).

As Attridge points out in his discussion of Boyhood and Youth, the writer has always been known for his reserve in relation to his private matters; yet one may find plenty of personal overtones in his writing, and his person has been under academic scrutiny especially since his moving to Australia (cf. Attridge, 2005: 37). Conversely, the act of writing has also become more of a central issue in Coetzee's own works as emerges from his Australian persona Elizabeth Costello from The Lives of the Animals (1999) and Elizabeth Costello (2003), up to and including the Mister C - or better, "Señor C" from Diary of a Bad Year (2008).

Contextually, his political positioning both in his works and in public lectures and statements has become more vocal, as Poyner points out (2009: 167). Poyner's volume, in its turn, is one in an impressive recent scholarly production on Coetzee's oeuvre and, in particular, on the themes of authorship and authority which, if anything, testifies to the sensibility of the academia to these themes: one may mention (just among those published in recent years) Strong Opinions: J. M. Coetzee and the Authority of Contemporary Fiction, edited by Chris Danta, Sue Kossew and Julian Murphet and J. M. Coetzee's Austerities, edited by Graham Bradshaw and Michael Neill. ${ }^{7}$

Before going back to Summertime I would like to briefly focus on Coetzee's Nobel Prize Lecture (2003) to further explore how his work offers a peculiarly fertile occasion to think of literature (postcolonial and otherwise) as event. This is an interesting case in point, as the physical presence of the writer (something just hinted at, if at all, in the written text) points at bodily 'exposure' as the precondition of the narration of the self, a self that "cannot be narrated" (Butler, 2005: 35). This presence is by now part and parcel of the performativity of any writer - a long-standing and widely recognized practice which includes public readings, academic conferences, literature festivals, interviews and many other public exposures of the writer's person together with her or his words. ${ }^{8}$ This exposure represents the predicament of writing: on the one hand "the stories do not capture the body to which they refer" (Butler, 2005: 38), and yet it is this very body in its social emergence and histories that the writer is ultimately asked to give an account of. It is this postcolonial body - black or white, male or female, clad in a sari or a suit or a cocktail dress - which has to be accounted for, "where it went and what it did" (38), as a preliminary condition of writing itself. It is this body, before and together with writing, which has to carry what Kobena Mercer has notoriously named "the burden of representation" (1990: 61-78) even in the case, such as Coetzee's, of a white male body with an Afrikaans family name and a South African background.

The live presence of the writer's body sheds light on at least one of the ways in which literature can be articulated as event. In discussing the Nobel lecture together with Elizabeth Costello (2003), published in the same year, Attridge notes:

[...] many of the pieces [from Elizabeth Costello] were first staged as public events in which the author was also the speaker; they lose that dimension on the page (though it is a fruitful exercise to attempt to recall it while reading), but as literary works to be 
read and lived through they remain, in an important sense, events (Attridge, 2004: 198; my italics).

Coetzee's Nobel lecture, titled "He and His Man", overturns this dynamic by being offered not as a traditional lecture but as a short story read by the writer himself, thus imbuing the act of reading with a dimension of actual performativity. Moreover, as the narrative unfolds in the trademark third person/present tense which characterizes Coetzee's life writing, the audience cannot help but overlap the writer himself with 'he', the third person narrator. ${ }^{9}$ Yet in due course the listeners realize that this 'he' is not the writer, 'he' is not even a writer (strictly speaking) but a most famous fictional character, Robinson Crusoe, writing about 'his man', writer Daniel Defoe.

These multiple layers of voices and subjectivities highlight the same "problem of authority" Kossew identifies in Coetzee's memoirs (2011: 9). In the introductory remarks to the story, and one of the very limited occurrences of the pronoun "I" in the lecture, Coetzee admits that "I can't remember which comes first, he or his man", thus disrupting the linear origination of character from writer. For the child Coetzee, innocent of the structures and strictures of authorship, it is not Robinson Crusoe who depends on Daniel Defoe for his very existence, but Defoe who has no reason to be in the Children's Encyclopaedia side by side with Crusoe, a usurper of Robinson's authority over his own narrative. To Coetzee the reader, it is not the writer but, indeed, the character who performs itself into being by authoring and legitimising his own author.

The performance of reading here articulates authority and authorship as diffused and disseminated, presuming - and performing - the existence of a spectator/reader/audience. Literary theory has explored the entrance of this interlocutor onto the scene of writing in current developments of reception theory, which Eagleton extensively refers to in his reflections on the event of literature. Here he notes how reading has recently become a central theoretical issue in literary criticism, so much so that now "the reader, once the less privileged, most disregarded member of the holy trinity that includes author and work, treated as a mere skivvy or dogsbody by a disdainful caste of authors, finally comes into her own as co-creator of the literary work" (2012: 185). The literary text only exists in the event of reading thanks to the many strategies through which reader and text come into relation with one another. For Eagleton, who extensively quotes Wolfgang Iser's work on the subject, reading hence becomes an "act of production" (190), which contains in nuce the possibility of elaborating always radically different meanings.

Nonetheless, Eagleton does not further address how the reader's ability to create meaning(s) lends a strong political agency to the act of reading; conversely, this issue is amply elaborated upon by Attridge. In his writing, the literary work of art is defined as such not because of a list of characteristics based on "everyday judgements" (Eagleton, 2012: 25), ${ }^{10}$ but because it prepares the ground of an encounter with the other, defined as "not other merely in the sense of being different, but [...] because the dominant culture within which it is produced and received depends on its exclusion" (Attridge, 2011: 333). Coetzee's autobiographic trilogy or, to use his own word, autrebiography 
(1992: 394) articulates this irruption of the other (autre) in the narrative account of oneself - an other who can assume the uncanny features of the writer himself, as happens in the Nobel prize lecture as well as in Summertime, where Coetzee is not only a character in his own work, but an 'already dead' character, who is unable to give an account of himself if not for the fragmented notebooks the reader is offered at the beginning and at the end of the book.

\section{Reading Summertime with one's eyes lowered}

Facing these first pages, the reader is initially offered no clue as to the author of either the notebooks or the notes in italics which close each entry and are written in the trademark male third person of Coetzee's previous memoirs: "To be expanded on: his father's response to the times as compared to his own; their differences, their (overriding) similarities" (2010: 6; here and elsewhere, italics in the text). Only as the reader proceeds and enters the chapter titled "Julia" is s/he offered more, though still sketchy information of what has just been read; more importantly, s/he realizes s/he was actually performing the role of one Dr. Frankl (who will be in due time identified as the eponymous Julia), who at the beginning of the chapter is addressed as reader by the still unnamed voice in italics: "Dr. Frankl, you have had a chance to read the pages I sent you from John Coetzee's notebooks from the years 1972-1975, the years, more or less, when you were friendly with him" (19). A few lines later it is Julia who asks one of the questions the reader might have been asking, that is, who wrote the notes at the end of each entry: "Coetzee wrote them himself. They are memos to himself, written in 1999 or 2000, when he was thinking of adapting those particular entries for a book" (20). The complex network of authorship unravels slowly and with difficulty under the reader's eyes, a reader who is left to patch up the pieces and try to make sense - if s/he feels the need to - of the many stories told in Summertime. Reading is thus both empowered and restrained by a text which continuously entangles the reader in its making.

This especially appears in the "Margot" chapter, the third in the book, where Margot, a cousin of Coetzee's, is reading a fictionalized version of her interview with the scholar, commenting here and there on his treatment of her words and eventually asking him to make some radical changes because the piece cannot "stand as it is" (152). The last page of the dialogue features more blank spaces than writing and typographical conventions trade places, with Margot speaking in the italics previously associated with the scholar's voice:

[Silence.]

And?

That's the end.

The end? But why stop there?

It seems a good place. She won't know me: a good line.

[Silence.]

Well, what is your verdict? 
My verdict? I still don't understand: if it is a book about John why are you including so much about me? Who is going to want to read about me - me and Lukas and my mother and Carol and Klaus?

You were part of your cousin. He was part of you. That is plain enough, surely. What I am asking is, can it stand as it is?

Not as it is, no. I want to go over it again, as you promised. (152)

According to Sue Kossew, "that the narrative does indeed appear to 'stand as it is' in the version we read suggests either that she did in the end agree to the changes or that the editor betrayed her trust by not making them" (2011: 18). Yet I believe there is a third option to be considered: that the conversation is happening 'as we read', that our reading is always chronologically coterminous with what we are reading. The event of literature shapes the page, whose authori(ali)ty is at best contested and which is explicitly just 'one version' of the text, a version which may become obsolete as characters argue over it.

This stress on editing - on the text being just one version in an apparently unending process of revision - is a recurring theme in Summertime, as the sources for John M. Coetzee's biography are undone one by one: witnesses are unreliable - sometimes they even believe they knew the writer and then find out "they had the wrong Coetzee" (225), as Mr. Vincent reports - and his own diaries are undependable if one is looking for some 'truth' about the writer:

I have been through the letters and diaries. What Coetzee writes there cannot be trusted, not as a factual record - not because he was a liar but because he was a fictioneer. In his letters he is making up a fiction of himself for his correspondents; in his diaries he is doing much the same for his own eyes, or perhaps for posterity. (225)

Yet to Mr. Vincent's point that live testimony is more reliable than writing, one of his interviewees - the French professor Sophie - retorts: "But what if we are all fictioneers, as you call Coetzee? What if we all continually make up the stories of our lives?" (226).

Life writing, one's own and another's, emerges here as an account of oneself, one which is necessary but at the same time refers to no truth except the regime of truth which allows it to exist - a regime of truth according to which the postcolonial writer is "public property", as Mr. Vincent calls it (226). Yet this text also asks for a different kind of reading - a reading with one's eyes lowered, as Rey Chow would put it: "this laying down of the gaze is the laying down of the weapon, the protective shield that separates us from the Other" (1998: 95). This does not mean, as it would happen in Huggan's postcoloniality, that postcolonial writing allows the reader to meet its 'Other' in the safe space of the commodification of the exotic. On the contrary, it requires the reader to surrender to the dissemination and ephemerality of the stories: as Mr. Vincent argues, "I am not interested in coming to a final judgement on Coetzee. I leave that to history. What I am doing is telling a story of a stage in his life, or if we can't have a single story then several stories from several perspectives" (217). 
By reading with one's eyes lowered, the event of literature excites a responsible readership by "bring[ing] the other into the field of the same, in the experience of the reader, listener or viewer" (Attridge, 2011: 332). This other is both reader and writer, an other to whom one has to relinquish the authority on the 'truth' of the account. The exposure of the partiality and ephemerality of this account undermines any claim to authorial voice or ontological fixedness, haunted as it is by the blank spaces surrounding the paragraphs and by that recurring word in square brackets - "[Silence]" - which 'resonates differently' with every reader and even, one might say, with every read: "silence here resonates differently. It is not equated with absence, lacuna or emptiness; it is a different sound, or [...] a 'soundless' space of resonance, and a language of its own" (Trinh, 1995: 8).

\section{Notes}

1. Derek Attridge first elaborates the idea of the work of literature as event in two companion books (cf. Attridge 2004a and 2004b), originally conceived as a single work, and only subsequently separated due to publishing issues (cf. Attridge, 2004b: 25): the joint genesis of the two works vouches for the significant influence of Coetzee's production in the elaboration of this theory, a debt mirrored in the present essay.

2. Here Attridge also clarifies that he intends to use 'emotion', 'affect' and 'feeling' interchangeably, without any methodological specificity attributed to any of these terms (2011: $330)$.

3. Barthes' own elaboration of the death of the author resonates with the performativity of literature as I am trying to sketch it here; although it will not be possible to explore these echoes in full, it is worth noting that Barthes argues that "to write is to reach, through a preexisting impersonality - never to be confused with the castrating objectivity of the realistic novelist that point where language alone acts, 'performs', and not 'oneself"' (1967: 3).

4. Huggan's pregnant discussion of the cultural policy in the case of the Booker Prize is quite beyond the scope of my argument here, but it is significant that Coetzee was the first writer to win twice a prize whose support of postcolonial literature "can [...] be seen within the wider context of a symbolic legitimation of 'multicultural' and/or exotically 'foreign' goods" (Huggan, 2001: 111).

5. I cannot here but mention the 'primary scene of address' Butler evokes at the beginning of Giving an Account of Oneself: "we start to give an account only because we are interpellated as beings who are rendered accountable by a system of justice and punishment" (2005: 10). Although later in the book Butler counterpoints fear with other relational affects as the grounds for one's own accountability, this primary emotion haunts her and my own sense of 'giving an account' as originated in the fear of not being recognizable not only as a writer (or a scholar, for that matter), but more generally (and painfully) as a subject and human being.

6. Huddard clearly marks the difference between autobiography and life writing, attributing most recent autobiographical fiction to the second category: "one of the reasons it needs to be called [life writing], rather than autobiography, is that the latter term privileges one particular way of writing a life, a way that for many critics is simultaneously too abstract, too masculine and Western" (2006: 2). 
7. Other books on the topic (to mention just monographs and miscellanies) include, together with Poyner's J. M. Coetzee and the Paradox of Postcolonial Authorship, Gillian Dooley's J. M. Coetzee and the Power of Narrative (2010) and Poyner's own J. M. Coetzee and the Idea of the Public Intellectual (2006); the work of Derek Attridge, David Attwell and Sue Kossew over the years should also be mentioned, as quoted elsewhere in this essay. Yet, this short and necessarily incomplete list does not represent an effort to offer a full bibliography of criticism on Coetzee, but only a way of highlighting the pervasiveness of the theme of authority and authorship in recent publications on his writing.

8. Although there will be no room for it in this essay, I believe a discussion on the role of the media (old and new) in the shaping of this public figure is in order here - especially as recorded performances are more and more available online, making the writer's public persona 'viral' through the Web.

9. The lecture is available, as video streaming and readable text, on the Nobel Prize website (http://www.nobelprize.org/mediaplayer/?id=555).

10. Eagleton identifies five factors which, alone or in combination, define a text as 'literary': “'people] mean by 'literary' a work which is fictional, or which yields significant insight into human experience as opposed to reporting empirical truths, or which uses language in a peculiarly heightened, figurative or self-conscious way, or which is not practical in the sense that shopping lists are, or which is highly valued as a piece of writing" (25). I have not been making use of Eagleton's categories here because, in the spirit of the critic's life-long struggle against theory, they fail to address the political specificity of the event of literature.

\section{References}

Attridge, Derek (2004a): The Singularity of Literature. London: Routledge. (2004b): J. M Coetzee and the Ethics of Reading: Literature in the Event. Chicago and London: University of Chicago Press.

- (2011): "Once More with Feelings: Art, Affect and Performance." Textual Practice 25(2): 329-343.

Barthes, Roland (1967): "Death of the Author." UbuWeb (accessed 16 May 2013). http://www.tbook.constantvzw.org/wp-content/death_authorbarthes.pdf

Bradshaw, Graham and Michael Neill, eds. (2013): J. M. Coetzee's Austerities. Farnham: Ashgate.

Butler, Judith (1997): Excitable Speech. New York: Routledge.

(2005): Giving an Account of Oneself. Ashland, Ohio: Fordham University Press.

Chow, Rey (1998): “The Dream of A Butterfly." In Rey Chow, Ethics after Idealism. TheoryCulture-Ethnicity-Reading. Bloomington and Indianapolis: Indiana University Press, 74-97.

Coetzee, J. M. (1992): Doubling the Point: Essays and Interviews, edited by David Attwell. Cambridge, Mass. and London: Harvard University Press.

(1997): Boyhood. London: Secker \& Warburg.

(1999): The Lives of the Animals. Princeton, N. J. and Chichester: Princeton University Press. 
(2002): Youth. London: Secker \& Warburg. (2003): Elizabeth Costello: Eight Lessons. Leicester: W. F. Howes.

(2008): Diary of a Bad Year. London: Harvill Secker.

(2010) [2009]: Summertime. Scenes from Provincial Life. London: Vintage.

Danta, Chris, Sue Kossew and Julian Murphet, eds. (2011): Strong Opinions: J. M. Coetzee and the Authority of Contemporary Fiction. New York: Continuum.

Dooley, Gillian (2010): J. M. Coetzee and the Power of Narrative. Amherst, NY: Cambria Press.

Eagleton, Terry (2012): The Event of Literature. New Haven and London: Yale University Press.

Huddard, David (2008): Postcolonial Theory and Autobiography. London: Routledge.

Huggan, Graham (2001): The Postcolonial Exotic. Marketing the Margins. New York: Routledge.

Kay, Jackie (2012): Red Dust Road. London: Picador.

Kossew, Sue (2011): “1. Scenes from Provincial Life.” In Tim Mehigan, ed., A Companion to the Works of J. M. Coetzee. Rochester, N. Y.: Camden House, 9-22.

Mercer, Kobena (1990): "Black Art and the Burden of Representation." Third Text 10: 61-78.

Poyner, Jane (ed.) (2006): J. M. Coetzee and the Idea of the Public Intellectual, Athens, Ohio: Ohio University Press.

- (2009): J. M. Coetzee and the Paradox of Postcolonial Authorship. Farnham: Ashgate.

Rushdie, Salman (2012): Joseph Anton. London: Jonathan Cape.

Said, Edward W. (1993): Culture and Imperialism. London: Chatto \& Windus.

Schechner, Richard (2013, third edition): Performance Studies: An Introduction. London and New York, Routledge.

Soueif, Ahdaf (2012): Cairo: My City, Our Revolution. London: Bloomsbury.

Stagoll, Cliff (2005): "Event." In Adrian Parr, ed., The Deleuze Dictionary. Edinburgh: Edinburgh University Press, 87-89.

Szafraniec, Asja (2007): Beckett, Derrida, and the Event of Literature. Stanford, Cal.: Stanford University Press.

Trinh T. Minh-ha (1995): “The Undone Interval.” In Lidia Curti and Iain Chambers, eds., The Postcolonial Question. Common Skies, Divided Horizons. London: Routledge, 3-16. 